\title{
Bibliometrics Contribution to the Metatheoretical and Domain Analysis Studies
}

\author{
Renata Cristina Gutierres Castanha*, Maria Cláudia Cabrini Grácio** \\ UNESP-Univ Estadual Paulista, 737 Hygino Muzzi Filho Avenue, 17525-900, Marilia, SP (Brazil), \\ *<regutierres@gmail.com>,**<cabrini@marilia.unesp.br>
}

Renata Cristina Gutierres Castanha graduated in mathematics and from the master's in information science from Univ Estadual Paulista. She is an active member of the Research Group for Metric Studies of Information.

Maria Cláudia Cabrini Grácio has bachelor's and master's degrees in statistics and a Ph.D. in Logic from the University of Campinas-UNICAMP. She is assistant professor in information science from UNESP-Univ Estadual Paulista and Coordinator of the Research Group for Metric Studies of Information. She has experience in the area of informetrics and logic.

Castanha, Renata Cristina Gutierres and Grácio, Maria Cláudia Cabrini. Bibliometrics Contribution to the Metatheoretical and Domain Analysis Studies. Knowledge Organization. 41(2), 171-174. 18 references.

\begin{abstract}
Along with the growth of scientific production, the bibliometric studies have become essential, providing relevant information about any domain while identifying, highlighting and viewing the scientific knowledge constructed within a theme, subject or knowledge area. This article approaches the bibliometric studies under the light of metatheory and domain analysis within the knowledge organization in information science. domain analysis and metatheory are considered significant contribution to bibliometric studies when emphasizing the need for epistemological, sociological and historical analyzes, as well as other qualitative approaches, encouraging researchers to reflect on the whole composition of the research object, by means of different methodological, theoretical and epistemological approaches. This study aims at contributing to the discourse of the theoretical aspects of bibliometric studies by presenting considerations concerning Hjørland's domain analysis, as well as Ritzer's metatheoretical approach, featuring discussions on major theories of a study field, since these approaches together provide a more complete qualitative view upon an area, here, represented by the bibliometric studies.
\end{abstract}

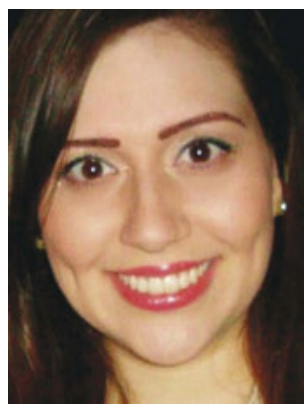

Received 1 August 2013; Accepted 1 August 2013

Keywords: knowledge, theory, domain analysis, information science, metatheory

\subsection{Introduction}

Within information science, knowledge organization stands as a mediator core between the production and use of information (Guimarães et al. 2004). For Dahlberg (1993), the information needs to be organized to become knowledge. The author also points out that the knowledge organization should be based on knowledge units: established concepts that do not work if isolated, but do if related. Accordingly, Hjørland and Albrechtsen (1995) claim that the best way to understand the information within information science itself is to study the knowledge domains of the discourse communities, in which analogous theories of thought, language and knowledge are highlighted. In that context, the research, through its scientific production, is a fundamental propelling element of the information and knowledge development, considering that the publication is intrinsic to research (Schwartzman 1984).

The publication of scientific results allows the socialization of the produced knowledge by means of its documentary record. Thus, in a spiraling cycle of production and communication of science, knowledge is made of social relations, from a social consensus (Guimarães 2000). In that context, the remarkable growth of scientific records has stimulated the analysis of this socialized knowledge and the development of tools to evaluate sci- 
ence has become indispensable. Among the evaluation methodologies of science, Bibliometrics stands out, consecrated since 1969 by Alan Pritchard, as studies to dissect the processes of written communication, the nature and development of scientific disciplines. For Hjørland and Albrechtsen (1995), the bibliometric analysis is a research area that provides valuable information about a discipline, as well as the relationships among disciplines, revealing social patterns of scientific communication. We aim to examine bibliometric studies under the light of domain analysis and Ritzer's metatheory, contributing to a better understanding and discussion of the structure and basis of these studies.

\subsection{Domain analysis, metatheory, and bibliometrics}

Thellefsen and Thellefsen (2004) define a domain as the demarcation of a certain knowledge, constructed from the interaction of concepts (knowledge units). However, according to these authors, the meaning of a concept is always relative to a particular domain, what differentiates one domain from the other. Within information science, Hjørland (2002) provides a theoretical perspective, linking theory and practice of the major concepts of the area, unifying different sub-disciplines, by means of domain analysis. The author suggests eleven approaches to study and know a domain and highlights that the use of those approaches together may provide a richer understanding of the field. Among the eleven approaches, the bibliometric studies stand out (Hjørland and Albrechtsen 1995) and, associated with those of a qualitative nature, such as epistemological, historical and critical, enrich the analysis of a subject or scientific domain (Hjørland 2002). These studies represent a powerful approach to domain analysis, since they trace sociological patterns of explicit recognition among individual documents (Danuello 2007).

Tennis (2008) states that the construction and development of the domain are joined by the ways in which discoveries are structured in the methodologies and in the theories. Because the Information Science exploits knowledge socially produced, released and used, the author states that, for a better understanding of it, a supplementation with the theoretical foundation of the social sciences and humanities must be inserted in its studies. In that context, there is metatheory, used by scholars in the field (Ritzer 1991 Vickery 1997 Hjørland 1998 Bates 2005 Tennis 2008) as a resource of the domain analysis, which provides aid to explain and discuss the existing theories.

Metatheory is based on research on theory itself (Bates 2005), i.e., it is a theory whose subject is the theory itself ("theory of the theory"). The set of concepts underlying the theory, i.e., the group of the fundamental ideas behind the researches and reflections concerning a phenomenon of interest in a particular research area (Vakkari 1997). In metatheory, the theory itself supports the theoretical-methodological development of the area treated as an object of study, upon which relationships, analyzes, discussions and reflections are established and, which contribute to the advancement of the theory. Therefore, it is a second order activity in which the concepts and methods of the theory are investigated. Metatheory doesn't directly deal with the practical problems (of first order) that make up the list of activities and issues of the area.

The concept of metatheory overlaps the concept of paradigm described by Kuhn (1970), which considers a paradigm as a metatheory, a combined theory and a methodology of a subject or expertise. The paradigm has a broader meaning than metatheory and, at the same time, metatheory is the core to any paradigm and defines it in many ways. In the sciences in general, a new paradigm resets all existing understanding with a new core of metatheories and research results. However, in the social sciences, many metatheories continue side by side: a metatheory will simply disappear and others will grow or change, but all are still of researchers' interest. Ritzer (1991) considers metatheory a critical analysis that examines the knowledge body studied by the scientists, reviews data, objects, facts definitions or phenomena, concepts and methods and examines the connections of the disciplines, according to criteria that assess the contribution of theories to the progress or stagnation of knowledge (Toledo-Nickels 2008).

Three main lines of metatheory in sociology are distinguished: as a means of obtaining a deeper understanding of an existing theory (named $\mathrm{Mu}$ ), as a prelude to the development of the theory (Mp) involving the study of existing the theory in order to produce new theories, and as a source of general theoretical perspectives (Mo), for the production of a new point of view and, which surmounts a portion or all of the sociological theory (Ritzer 1991). The $\mathrm{Mu}$ is associated with theory studies and communities of theoretical authors, as well as their social and intellectual contexts. Ritzer (1991) produces a typology which deals with varieties of $\mathrm{Mu}$, by proposing a diagram with four directional axes: internal, external, intellectual and social. The internal axis refers to existing studies within sociology, while the external one refers to phenomena found outside it, but with impact on it. The intellectual axis refers to the cognitive structure: theories, metatheoretical tools, ideas borrowed from other disciplines, and so on. The social dimension refers to the sociological structure: schools, the effect of individual factors on sociological background, the impact of the society, among others. 
From Ritzer's perspective (1991), bibliometrics consists of a metatheoretical analysis which contributes to the understanding of an existing theory $(\mathrm{Mu})$. Grácio and Oliveira (2012) corroborate this view by stating that it consists of the knowledge body related to the evaluation of the information produced, referring to studies of theoretical-conceptual nature when contributing to the advancement of knowledge of the theme itself, proposing new concepts and indicators, as well as reflections and analyzes relating to the area and of methodological nature when they propose to give support to the theoretical work of the area where they are applied.

Within bibliometrics, the intellectual and social axes stand out, considering that its studies aim at identifying, highlighting and allowing visualization of the research front, the scientific collaboration networks, as well as the cognitive networks, the invisible college and major schools of thought, among others, in a knowledge domain. They also present relations with conceptual tools from other disciplines, used as analytical resources that act as stimulation for the development of new theories, such as the network analysis approach in oder to identify and visualize the connections among groups of sociologists who subscribe to one or another theoretical approach (Ritzer 1991). Therefore, bibliometric approach provides a valuable understanding both to the information design and to the theoretical understanding of the social process that permeates the information, including historical processes.

\subsection{Final remarks}

Theoretical approaches are multiple and complementary. In every field, the study of phenomena is enriched when observed from different theoretical perspectives. Approaches of domain analysis and of metatheory are examples of consistent approaches, which together, provide a more complete understanding of the object of study, providing a more consistent understanding about the whole complexity of the study field.

Therefore, domain analysis and metatheory contribute significantly to bibliometric studies, while stressing the need for epistemological, sociological, and historical analyzes, and other qualitative approaches, encouraging researchers to contemplate the whole theme of the research object, by using different methodological, theoretical and epistemological approaches, enabling a more consistent analysis of the survey data.

\section{References}

Bates, Marcia J. 2005. An introduction to metatheories, theories and models. In Fisher, Karen E., Erdelez
Sanda and McKechnie, Lynne, eds., Theories of information behavior. Medford, New Jersey: Information Today.

Dahlberg, Ingetraut. 1993. Knowledge organization: its scope and possibilities. Knowledge organization 20: 211-9.

Danuello, Jane Coelho. 2007. Produção científica docente em tratamento temático da informação no Brasil: uma abordagem métrica como subsídio para a análise de domínio. Master dissertation. Marília, São Paulo: Universidade Estadual Paulista.

Grácio, Maria Cláudia Cabrini and Oliveira, Ely Francina Tannuri de. 2012. Inserção e o impacto internacional da pesquisa brasileira em estudos métricos: uma análise na base Scopus. In XIII ENANCIB - Encontro Nacional de Pesquisa em Ciência da Informação, Rio de Janeiro. Anais. Rio de Janeiro: FioCruz, pp. 1-20.

Guimarães, José Augusto Chaves. 2000. Perspectivas de ensino e pesquisa em organização do conhecimento em cursos de biblioteconomia do Mercosul: uma reflexão. In Encuentro de EDIBCIC, 5., Granada. La formación de profesionales e investigadores de lainformación para lasociedaddelconocimiento: Actas. Granada: Universidad de Granada, Facultad de Biblioteconomía y Documentación, pp. 206-16.

Guimarães, José Augusto Chaves, Danuello, Jane Coelho and Menezes, Pedro José. 2004. Formação para a atuação profissional em organização de conteúdos informacionais: uma análise das bases teórico-pedagógicas dos cursos de Biblioteconomia do Mercosul. In Valentim, Marta Lígia Pomim, ed., Atuação profissional na área de informação. São Paulo: Polis, pp. 167-87.

Hjørland, Birger. 1998. Theory and metatheory of information science: a new interpretation. Journal of documentation 54: 606-21.

Hjørland, Birger. 2002. Domain analysis in information science: eleven approaches - tradional as well as innovative. Journal of documentation 58: 422- 62.

Hjørland, Birger and Albrechtsen, Hanne. 1995. Toward a new horizon in information science domain analysis. Journal of the American Society for Information Science 46: 400-25.

Kuhn, Thomas S. 1970. The structure of scientific revolutions. Chicago: The University of Chicago Press.

Pritchard, Allan and Groos, Ole V. 1969. Documentation notes. Journal of documentation 25: 344-9.

Ritzer, George. 1991. Metatheorizing in sociology. NY: Lexington Books.

Schwartzman, Simon A. 1984. A política brasileira de publicações científicas e técnicas: reflexões. Revista brasileira de tecnologia 15 n.3: 25-32.

Tennis, Joseph T. 2008. Epistemology, theory and methodology in knowledge organization: toward a classification, metatheory, and research framework. Knowledge organization 35: 160-82. 
Thellefsen, Torkild Leo and Thellefsen, Martin Muderspach. 2004. Pragmatic semiotics and knowledge organization. Knowledge organization 31: 177-87.

Toledo-Nickels, Ulises. 2008. El esquema metateórico de Ritzer desde la metodología de los programas de investigación. Cinta de moebio 33: 204-18.

Vickery, Brian Campbell. 1997. Metatheory and information science. Journal of documentation 53: 457-76.
Vakkari, Pertti. 1997. Information seeking in context: a challenging metatheory. In Vakkari, Pertti, Savolainen, Reijo and Dervin, Brenda, eds., Information Seeking in Context. Proceedings of International Conference Research in Information Needs, Seeking and Use in Different Contexts. Tampere: Taylor Graham, pp. 451-64. 